\title{
MÉSZÁROS ÁDÁM
}

\section{A jogellenes állapot fenntartásával megvalósuló büncselekmények}

\begin{abstract}
A büntetőjog tudománya ismeri és megkülönbözteti az úgynevezett állapotés tartós büncselekményeket. Mindkettőre az jellemző, hogy valamely jogellenes állapot fenntartásában állnak. Tipikus példaként a személyi szabadság megsértését és a lőfegyverrel visszaélés tartásos változatát szokás említeni.

A tanulmány alapgondolata szerint a jogellenes állapot fenntartásával megvalósuló büncselekmények tana nem tekinthető lezártnak, mivel számos olyan kérdés vetődik fel, amellyel talán érdemes foglalkozni. A tipikusnak tekintett eseteken túl ugyanis vannak olyan büncselekményi tényállások, amelyek kapcsán alappal vetődhet fel a jogi tárgy elleni támadás elhúzódása, a befejezettség és a bevégzettség stádiumának szétválása.
\end{abstract}

\section{Jogirodalmi álláspontok}

Angyal Pál tankönyvében a természetes egység keretében foglalkozott a két büncselekménytípussal. A tartós büncselekmények jellemzőit abban látta, hogy ezeknél a tevékenység bizonyos időn keresztül megszakítás nélkül ismétlődik, és az eredményt mint jogellenes állapotot nemcsak létrehozza, hanem fenn is tartja. Példaként a személyes szabadság megsértését említette, amelynek lényege, hogy amikor a tettes a sértettet letartóztatja, majd órákig, esetleg napokig nem engedi szabadon, a cselekmény mindaddig elkövetés alatt áll, míg a sértett a szabadságát vissza nem nyeri. Az állapot-büncselekmény Angyal szerint rendszerint egyetlen tevékenységből áll, ez azonban hosszabb ideig tartó jogellenes állapotot létesít. Példaként a gyermekcsem-

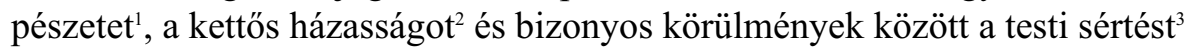
hozta fel.

A kétfajta bủncselekményi kategória közti különbséget Angyal abban látta, hogy a tartós büncselekménynél a jogellenes helyzet fenntartása is elkövetési tevékenység, az állapot-büncselekmény esetén a jogellenes állapot létesítésével a bűncselekmény be van végezve. A tartós büncselekménynél az elkövetés, az állapot-büncselekménynél az állapot a tartós. ${ }^{4}$ 
Heller Erik a pillanatnyi büncselekményekkel a tartós vagy folytonos büncselekményeket állította szembe. Utóbbiak lényege, hogy eredményük „, csak úgy válhat tartóssá, ha azt folytonosan újra elöidézik. Ha ezeknek tényálladékát a jogforrás úgy határozza meg, hogy az az eredménynek folytonosan újra elöidézésében áll, a büncselekményt a tartós, ill. folytonos büncselekmények közé kell sorolni." "s

$\mathrm{Az}$ 1950. évi II. törvényt jegyzetekkel ellátó Kádár Miklós az állapotbüntett lényegét abban látta, hogy az valamely, a társadalomra veszélyes állapot előidézésével valósul meg. Véleménye szerint az ilyen büntett elkövetése mindaddig folyamatban van, amíg a társadalomra veszélyes állapot nem szünt meg. Példaként a fegyverrejtegetést hozta fel, ahol a társadalomra veszélyes állapot addig tart, amíg az elkövető a fegyvert rejtegeti. Az állapotbüntettől megkülönböztette a tartós vagy folyamatos büntettet, amely állandó, folyamatos cselekvésben áll. Erre példaként a személyes szabadság megsértésének törvényellenes fogva tartással megvalósuló esetét jelölte meg. ${ }^{6}$

Tokaji Géza méltán híres monográfiájában az elévülés kapcsán tárgyalta a két büncselekményi kört. Itt a szoros értelemben vett állapot-büncselekmények lényegét abban látta, hogy ebben az esetben a befejezetté válást követö jogellenes állapot anélkül tartozik hozzá a törvényi tényálláshoz, hogy ez az elkövetési magatartás további folytatását tételezné fel. Példaként a személyi szabadság megsértését hozta fel. Tokaji szerint mindezzel szemben a tartós büncselekményeket az jellemzi, hogy bár az elkövetési magatartás első mozzanatával befejezetté válnak ugyan, maga az elkövetési magatartás is több-kevesebb ideig folytatódik. Példaként az összeesküvést, illetve az olyan büncselekményeket említette, amelyek elkövetési magatartása az engedély nélküli birtoklásban tartás. ${ }^{7}$

Wiener A. Imre a stádiumok kapcsán azt írta, hogy a büncselekmény akkor befejezett, amikor az utolsó tényállási elem is megvalósul. Ezt követően tért ki a tartós büncselekményekre, amelyek Wiener szerint azok, amelyekben az elkövetési magatartás valaminek a tartása (például fegyver, kábítószer), és ezek mindaddig tartanak, ameddig az elkövetőnél van a dolog, és a befejezettség akkor kezdődik, amikor ez az állapot megszünik. ${ }^{8}$ (Zárójelben jegyzem meg ennek az álláspontnak a helytelenségét, valójában a büncselekmény befejezetté a tényállási elemek megvalósulásával válik, a bevégzetti szak fejeződik be akkor, amikor a jogi tárgy elleni támadás megszünik.)

Földvári József a törvényi tényállás fajainak ismertetése során utalt arra, hogy az aktív magatartással megvalósuló bủncselekmények között megkülönböztetett figyelmet érdemelnek azok, amelyek esetén a törvényhozó nem 
egy jogellenes helyzet előidézését nyilvánítja büntetendővé, hanem egy jogellenes helyzet, állapot fenntartását, így például robbanóanyag birtokban tartását. Ezeket a büncselekményeket nevezte Földvári állapotbüncselekményeknek. ${ }^{9}$ A stádiumok tárgyalása során Földvári arra hívta fel a figyelmet, hogy azon büncselekmények esetében, amelyek tényállását a törvényhozó oly módon határozza meg, hogy a befejezettség stádiuma maga is egy folyamattá válik, amelynek van kezdete, tartama és vége (állapot-büncselekmények), a befejezettség a jogellenes állapot létrehozásával megvalósul (a büncselekmény a befejezettség stádiumában van), ez a stádium azonban mindaddig fennáll, amíg az említett tárgyak (Földvári a robbanóanyaggal/robbantószerrel, illetve a lőfegyverrel/lőszerrel visszaélést hozza fel példának) ki nem kerülnek az elkövető birtokából. Földvári szerint ilyen esetben a befejezettségnek van egy kezdő és egy végső időpontja. Az előbbinek a többi stádiumtól való elhatárolás, az utóbbinak az elévülés és a bünsegély megállapíthatósága szempontjából van jelentösége. ${ }^{10}$

A korábbi budapesti tankönyvben a különböző szerzők némiképp különbözően vélekedtek a büncselekmény e fajtájáról. Békés Imre az elkövetési magatartás mint szükséges ismérv fejezetcím alatt az elkövetési magatartás időbelisége szempontjából különböztette meg a mozzanatos és a folyamatos büncselekményeket. Utóbbiak időben huzamosan kiterjedve tartanak, ami azt jelenti, hogy „, az elkövetési magatartás tanúsitásával ugyan a büncselekmény befejezetté válik, ez a befejezettség azonban, állapotszerüen tovább tart, mégpedig mindaddig; amig a folyamat be nem fejezödik, illetöleg az állapot meg nem szünik" "II. Példaként a „fegyverrejtegetést" hozta fel, és azt állította, hogy a löfegyver/lőszer jogosulatlan megszerzésével a büncselekmény befejezetté válik, ez a befejezettség pedig addig tart, amíg a rejtegető a fegyver birtoklásával fel nem hagy (például megsemmisíti), vagy amíg a büncselekményt a hatóság fel nem deríti. ${ }^{12}$ Ezzel a felfogással kapcsolatban azt kell megjegyezni, hogy a lőfegyver jogosulatlan megszerzése önmagában befejezett büncselekményt valósít meg. Ettől különböző elkövetési magatartás a löfegyver tartása. Két különböző elkövetési magatartásról van tehát szó!

Folyamatos büncselekmények helyett úgynevezett tartós vagy állapotbüncselekményekről szól ugyanebben a tankönyvben Molnár Gábor a befejezett büncselekmény tárgyalása során. Mielőtt tovább haladnánk, arra érdemes felhívni a figyelmet, hogy a szerző a két elnevezést szinonimaként használja, és e büncselekmények lényegét abban látja, hogy a jogellenes állapot létrejöttével befejezetté válnak. Molnár azonban megemlíti a bevégzettség szakát is: példája szerint a személyi szabadságtól megfosztás esetén bár 
a büncselekmény a sértett személyi szabadságától megfosztása pillanatában befejeződik, azonban a tartós megfosztottság ugyancsak a tényállás keretei közé eső magatartás, így a jogi tárgy elleni támadás addig tart, amíg a jogellenes állapot fennáll, a bevégzettség tehát csak e jogellenes állapot megszünésével állapítható meg. ${ }^{13}$ Molnár összegzése szerint a befejezettség nem más, mint egy tartós állapot, amelynek kezdete a kísérlet és a befejezett büncselekmény elhatárolása, míg a vége az egyéb jogkövetkezmények (társtettesség, bünsegély, jogos védelem) szempontjából jelentős. ${ }^{14}$

Még mindig az említett tankönyvben, annak a büntethetőség elévüléséröl szóló fejezetében Sinku Pál a Btk. szövegére utalva arra hívja fel a figyelmet, hogy az állapot-büncselekmény megnevezés több büncselekménytípust foglal magában. Ezek az elévülés kezdő napjának meghatározása szempontjából azonosan bírálandók el, azonban más szempontból lényeges különbségek vannak közöttük. Sinku szerint ebbe a körbe tartoznak azok a büncselekmények, amelyek elkövetési magatartása tartós, folyamatos vagy ismétlődő jellegü. Az ilyen büncselekmények esetén a cselekmény befejeződik a jogellenes állapot létrehozásával, az elévülés kezdő időpontja azonban a jogellenes állapot megszünéséhez kötődik. ${ }^{15}$

Nagy Ferenc szerint a tartós és állapot-büncselekmények jellemzője, hogy ezek hatásaként, eredményeként az elkövető viszonylag hosszú vagy hoszszabb időn át tartó jogellenes helyzetet, állapotot hoz létre. A tartós büncselekmény a tényállás megvalósításával befejezett ugyan, de a jogi tárgy elleni támadás - általában az elkövető akaratától függően - megújulhat, folytatható, és olyan hosszú ideig tart, amíg az általa teremtett jogellenes helyzet vagy állapot fennmarad. Példaként egyrészt a személyi szabadság megsértését említi, amely a személyi szabadságtól való megfosztás pillanatában befejezetté válik, de ezzel kezdetét veszi a jogellenes állapot, amely addig tart, míg a sértett a szabadságát vissza nem nyeri. Másrészt a magánlaksértést, amely a tettesnek a lakásba stb. történő jogtalan behatolásával befejezett, és ami szintén olyan hosszú ideig tart, amíg a tettes a lakásban tartózkodik.

Az állapot-büncselekmény esetén Nagy szerint a jogellenes állapot létrehozásával már megvalósul a törvényi tényállás, azonban a jogellenes állapot fenntartására, megújítására a tettes részéről általában nincs szükség. Idézi Angyal megfogalmazását, amely szerint az állapot-büncselekménynél nem az elkövetés, hanem az állapot tartós. Példaként a robbanóanyaggal vagy robbantószerrel visszaélés, illetve a lőfegyverrel vagy lőszerrel való visszaélés engedély nélküli tartásos változatát hozza fel. ${ }^{16}$ 


\section{Törvényi rendelkezések}

A hatályos Btk. (2012. évi C. törvény; Btk.) a büntethetőség elévülése kapcsán úgy rendelkezik, hogy az elévülés kezdő napja olyan büncselekmény esetén, amely jogellenes állapot fenntartásában áll, az a nap, amikor ez az állapot megszünik [27. § d) pont]. A törvény miniszteri indokolása azt tartalmazza, hogy ezt a büncselekményi kört az ítélkezési gyakorlat állapot-büncselekménynek hívja.

A korábbi Btk. (1978. évi IV. törvény), amely először tartalmazott kifejezett rendelkezést az állapot-büncselekmények elévülésére vonatkozóan, teljes hatályának idején (1979. július 1. - 2013. június 30.) ugyanezt a rendelkezést tartalmazta [34. § d) pont]. A miniszteri indokolás ezt a büncselekményi kört állapot-büncselekménynek nevezi, és jellemzőjéül azt határozza meg, hogy a jogellenes állapot létrehozásával már befejezetté válik, a befejezett büncselekmény viszont mindaddig fennmarad, amíg a jogellenes állapot véget nem ér. ${ }^{17}$

\section{Problémafelvetés}

Az eddigiekböl látható, hogy a tartós és állapot-büncselekményeknek sem az elnevezése, sem a fogalma nem azonos a különböző szerzőknél: van, aki szinonimaként kezeli, van, aki meg sem különbözteti egymástól, és van, aki eltérő fogalmat ad a büncselekmények e fajtáinak. Annyi a bizonyos csupán, hogy olyan büncselekményekről van szó, amelyek valamilyen jogellenes állapot fenntartásában állnak.

A továbbiakban azt érdemes megvizsgálni, hogy milyen különbségek tehetők a jogellenes állapot fenntartásában megnyilvánuló büncselekmények között.

Az egyik gyakran felhozott példa a lőfegyverrel/löszerrel visszaélés, de lényegében ugyanilyen büncselekmény a kábítószer birtoklása is. E büncselekmények esetén a tartásos elkövetési magatartás vonható a tartós vagy állapot-büncselekményi kategóriába. Közös jellemzőjük azonban, hogy a tartást megelőző megszerzés még nem minősül tartásnak, mivel azt a törvény külön büntetni rendeli, és így nem is része a jogellenes állapot fenntartásának. Tehát a megszerzéssel még nem kezdődik meg a jogellenes állapot, azaz a megszerzés nem tényállásszerü magatartás a tartás vonatkozásában. Kérdésként vetődhet fel, hogy vajon a tartás csak akkor állapítható meg, ha a megszerzés jogszerü volt. Erre vonatkozóan azt lehet megállapítani, hogy a 
robbanóanyaggal vagy robbantószerrel visszaélés esetén a tankönyv- és kommentárirodalom azt hangsúlyozza, hogy a tartás csak akkor valósít meg önálló elkövetési magatartást, ha a készítés vagy a megszerzés jogszerü volt ${ }^{18}$, azaz a megelőző magatartások vagy nem jogellenesek, vagy az elkövetési tárgy nem megszerzéssel, hanem találással került az elkövető birtokába. ${ }^{19} \mathrm{~A}$ kábítószer birtoklása kapcsán azonban az az álláspont figyelhető meg, hogy a tartásos változat akkor is megállapítható, ha a birtokállapot létrejötte (termesztés, előállítás, megszerzés) tisztázatlan ${ }^{20}$. Ez a megoldás voltaképp nem mást tesz, mint eljárásjogi megoldást (bizonyítottság hiánya) próbál adni egy anyagi jogi kérdésre. Logikailag talán annak elfogadása lenne a leghelyesebb, hogy a tartás mint elkövetési magatartás csak akkor állapítható meg, ha a megszerzés jogszerü volt (legalábbis nem volt jogellenes). Kétségtelenül eljárásjogi könnyebbséget jelentene, ha akkor is a tartást állapítanánk meg, ha a megszerzés nem bizonyítható, ez azonban véleményem szerint a tényállástan dogmatikáját tekintve nem tartható. Ami viszont bizonyos, hogy a megszerzés még nem a tartás mint folyamat része.

Egy másik, gyakran említett példa a személyi szabadság megsértése, amit az követ el, aki mást személyi szabadságától megfoszt [Btk. 194. § (1) bek.]. Amennyiben az elkövető a passzív alanyt a személyi szabadságától szándékosan megfosztja, például bezárja egy helyiségbe, a büncselekmény a bezárás pillanatában befejezetten megvalósul. Azaz már maga a jogellenes állapot létrehozása is része a jogellenes állapot fenntartásában megnyilvánuló bủncselekménynek, tényállásszerü elkövetési magatartásnak tekinthető. Szintén ilyen a magánlaksértés vétségének [Btk. 221. § (1) bek.] azon változata, amely annak a cselekményét rendeli büntetni, aki más lakásába erőszakkal bemegy. Ebben az esetben maga a bemenetel már a jogellenes állapot fenntartásának a része. Fel kell hívni azonban a figyelmet arra, hogy a büncselekmény másik változata, amikor az elkövetö a lakásba jogszerủen megy be, azonban erőszakkal bent marad, más helyzetről van szó: ekkor a jogellenes állapotot lehetővé tevő magatartás nem tényállásszerü, és nem is minősül büncselekménynek.

Összegzésként azt érdemes kiemelni, hogy ami a példaként felhozott büncselekmények kapcsán különbségként legfeljebb megjelölhető, hogy magának a jogellenes állapotnak a létrehozása önmagában büncselekménynek minősül-e, illetve az a jogellenes állapot fenntartását meghatározó tényállás alá vonható-e,vagy sem. Ezen túl valójában e büncselekményi kategóriák elhatárolásának valódi dogmatikai vagy felelősségtani jelentősége nincs. Így nincs különbség az elévülés szabályait illetően, és a befejezettség-bevégzettség 
konzekvenciái is ugyanazok mindkét büncselekményi körben, mivel a lényeg mindkét esetben ugyanaz: egy jogellenes állapot fenntartása. A továbbiakban ezért a jogellenes állapot fenntartásában megvalósuló büncselekményeket összhangban a törvényi rendelkezésekkel - állapot-büncselekményeknek nevezem.

\section{Az állapot-büncselekmények és az elkövetési magatartás}

Jogellenes állapot létrehozható tevékenységgel és mulasztással is. Az előbbire példa a magánlaksértés vétségének az a változata, amikor az elkövető a sértett lakásába erőszakkal megy be. Az utóbbira példa ugyanezen büncselekménynél maradva, ha az elkövető a sértett lakásába jogszerüen (tehát büntetőjogilag nem értékelhető magatartással) megy be, majd erőszakkal bent marad. Mindkét esetben a benntartózkodás ideje jelenti a jogellenes állapotot. A jogellenes állapot fenntartásával megvalósuló büncselekmény létrejöttét (és annak jogi következményeinek beálltát) nem teszi kizárttá a jogellenes állapotot létrehozó, megelöző aktív magatartást követő puszta passzivitás. ${ }^{21}$ Ilyen például a személyi szabadság megsértése (Btk. 194. §), vagy az azt magában foglaló emberrablás (Btk. 190. §). Ezek a büncselekmények - legalábbis a személyi szabadságtól megfosztás tekintetében - nyitott törvényi tényállások, amelyek megvalósíthatók akár tevéssel, akár mulasztással. A jogellenes állapot létrehozása azonban mindig tevéssel történik. Az állapot fenntartása az, amely vagy mulasztásban nyilvánul meg (ha például az elkövető véletlenül, tudomásán kívül - tehát büntetőjogilag nem értékelhető magatartással bezárja a sértettet egy helyiségbe, majd később ezt észleli, és nem engedi ki, ez esetben az elkövető megelőző, sérelmet létrehozó tevékenységén alapul a mulasztás miatti felelősséghez szükséges speciális jogi kötelezettség), vagy a jogellenes állapotot szándékosan létrehozó, megelőző aktív magatartást követő puszta passzivitásban. Mivel utóbbi esetben a személyi szabadságtól megfosztott állapotot büntetôjogilag értékelhető aktív magatartás hozta létre, ez kizárttá teszi a mulasztásos változat megvalósulását. Másként fogalmazva: ilyenkor a büncselekményt tevéssel elkövetettnek kell értékelni. 


\section{A befejezettség és a bevégzettség szétválásának konzekvenciái}

A jogellenes állapot fenntartásával megvalósuló büncselekmények esetén lehetőség van arra, hogy a befejezetti és a bevégzetti stádium elkülönüljön egymástól. Ennek lényege az, hogy a büncselekmény tényállási elemeinek megvalósulása esetén a büncselekmény befejezetté válik ugyan, viszont ha a jogi tárgy elleni támadás ez után is fennáll, a büncselekmény akkor lesz bevégzett, amíg ez a támadás meg nem szünik. E két büncselekményi stádium szétválásának több konzekvenciája lehet.

a) Maga a Btk. említi meg azt, hogy az elévülés kezdő napja ilyen esetben az a nap, amikor a jogellenes állapot megszünik [27. § d) pont].

b) Ezen kívül a jogtudomány és joggyakorlat egyéb konzekvenciákat is megemlít.

c) Az egyik ilyen, hogy a jogellenes állapot fenntartásában megnyilvánuló büncselekmény természetes egységet alkot ${ }^{22}$, azaz az elkövető terhére egyéb körülmény fennállásának hiányában - egyetlen büncselekmény állapítandó meg.

d) Jogellenes állapot fenntartásában megnyilvánuló büncselekmény esetén a jogos védelmi helyzet fennáll a jogi tárgy sérelmének megszüntéig.

e) A befejezettség és a bevégzettség elválása esetén, a jogi tárgy sérelmének ideje alatt a büncselekmény önálló tettese mellé bünsegéd, illetve adott esetben tettestárs csatlakozhat. Kivételes esetben az sem kizárt, hogy az állapot-büncselekménybe a befejezetté válást követően csatlakozó elkövetőt felbujtóként kelljen felelösségre vonni. ${ }^{23}$

f) Adott esetben előfordulhat, hogy a befejezetté válás után kerül sor az elkövető részéről minősítő körülmény megvalósítására.

g) Logikusnak tünik az az álláspont, amely a bevégzetti szaktól tartja megnyílhatónak a magánindítvány előterjesztésének a lehetőségét. ${ }^{24}$ Ennek egyelőre sajnos némiképp ellentmond a büntetőeljárási törvény, amely szerint a magánindítványt attól a naptól számított harminc napon belül kell elöterjeszteni, amelyen a magánindítványra jogosult a bűncselekmény elkövetöjének kilétéről tudomást szerzett [Be. 173. § (3) bek.]. Gyakorlati megoldást jelenthet az a megengedő szabály, amely a közvádra üldözendő büncselekmények esetén a határidő elmulasztása esetére igazolást enged [Be. 173. § (4) bek.]. Ez azonban - véleményem szerint - nem olyan elvi élü szabály, mint ami az elévülés esetére vonatkozik. 


\section{A jogellenes állapot fenntartásával megvalósuló (állapot-) büncselekmények lehetséges esetei}

Ebben a fejezetben azokat a büncselekményi tényállásokat és elkövetési magatartásokat tekintem át, amelyeket a tartós/állapot-büncselekmények tárgyalása kapcsán az ezzel foglalkozó szerzők nem szoktak tipikus példaként említeni. Ebből kifolyólag a korábban már említett személyi szabadság megsértése, magánlaksértés, lőfegyverrel/löszerrel visszaélés, kábítószer birtoklása e helyütt figyelmen kívül marad.

\section{A tevékenység folytatása}

Állapot-bűncselekményt valósíthatnak meg az olyan tényállások, amelyek elkövetési magatartása valamely tevékenység folytatása, végzése.

Annak belátása, hogy a tevékenység folytatása mint elkövetési magatartás idetartozik, talán a legkevésbé problematikus, mivel ez nyilvánvalóan tartós, folyamatos vagy ismétlődő jellegü tevékenységet tételez fel.

Ilyen elkövetési magatartások találhatók:

a) a háborús büncselekmények köréböl a háború idején támadás folytatása [védett tulajdon elleni támadás, Btk. 153. § (1) bek.];

b) az állam elleni büncselekmények köréből a hírszerző tevékenység folytatása [kémkedés, Btk. 261. § (1) bek., illetve kémkedés az Európai Unió intézményei ellen, Btk. 261. §/A §]; végül

c) a köznyugalom elleni bűncselekmények köréből a háborús hírverés, illetve terrorizmust támogató hírverés folytatása (háborús uszítás, Btk. 331. §) esetében.

A jogellenes tevékenység folytatása tehát voltaképp egy folyamatként értelmezhetö, amely egy jogellenes helyzetet teremt, ami időben kiterjedhet, így egy jogellenes állapotot tart fenn. E jogellenes állapot fennállása alatt a jogi tárgy elleni támadás tart, a jogi tárgy sérelmet szenved.

\section{Cselekmény vagy tevékenység végzése}

A valamilyen cselekmény vagy tevékenység végzése már problematikusabb, ez ugyanis a Btk.-ban többféle módon jelenik meg, úgymint:

a) beavatkozás végzése [beavatkozás az emberi génállományba, Btk. 168. § (1) bek.; születendő gyermek nemének megválasztása, Btk. 170. §; egészségügyi önrendelkezési jog megsértése, Btk. 218. § (1), illetve (3) bek.]; 
b) kutatás végzése [emberen végezhető kutatás szabályainak megszegése, Btk. 171. §; embrióval vagy ivarsejttel végezhető kutatás szabályainak megszegése, Btk. 172. § (1) bek., illetve 173. § (1) bek.];

c) tevékenység végzése, amely lehet

- közvetítő tevékenység végzése [kábítószer-prekurzorral visszaélés, Btk. 183. § (1) bek. a) pont],

- vad elejtésére, elfogására; gerinces állat elejtésére vagy elfogására, halfogásra irányuló tevékenység végzése [orvvadászat, Btk. 245. § a), illetve c) pont, 246. §],

- hulladékgazdálkodási tevékenység, hulladékkal más jogellenes tevékenység végzése [a hulladékgazdálkodás rendjének megsértése, Btk. 248. § (1) bek. a) pont],

- ügyvédi, jogtanácsosi vagy közjegyzői tevékenység végzése [zugírászat, Btk. 286. § (1) bek.],

- színlelt gazdasági tevékenység végzése [gazdasági csalás, Btk. 374. § (1) bek.],

- pénzügyi tevékenység végzése [pénzmosás, Btk. 399. § (1) bek. a) pont, illetve (3) bek. b) pont, 400. § (1) bek. b) pont],

- pénzügyi szolgáltatási (stb.), befektetési szolgáltatási (stb.), biztosítási (stb.), önkéntes kölcsönös biztosítópénztári (stb.) tevékenység végzése (jogosulatlan pénzügyi tevékenység, Btk. 408. §);

d) szexuális cselekmény végzése [szexuális erőszak, Btk. 197. § (2) bek.; szexuális visszaélés, Btk. 198. § (1), illetve (4) bek.; vérfertőzés, Btk. 199. § (1) bek.];

e) engedélyhez kötött titkos információgyüjtés, illetve titkos adatszerzés engedély nélküli végzése [jogosulatlan titkos információgyüjtés vagy adatszerzés, Btk. 307. § (1) bek.];

f) megbízhatósági vizsgálat ügyészi jóváhagyás nélküli végzése [jogosulatlan megbízhatósági vizsgálat végzése, Btk. 308. (1) bek. a) pont].

Kérdésként vetődik fel, hogy ezek a büncselekmények lehetnek-e állapotbüncselekmények. Segítségül az szolgálhat, ha megnézzük, hogy milyen jogi tárgyat sértenek, és a védett jogi tárgy - az elkövetési magatartásra is figyelemmel - alkalmas-e arra, hogy a sértése időben elhúzódjon. Másként fogalmazva, azt kell megvizsgálni, hogy a befejezettséghez szükséges tényállási elemek megvalósulása esetén a jogi tárgy tovább sérthető-e. 


\section{Beavatkozás végzése}

A beavatkozás az emberi génállományba büntettének (Btk. 168. $\left.\S^{25}\right)$ védett jogi tárgya az egyik álláspont szerint az emberi, a magzati, valamint az emberi embrió génállományának a megváltoztathatatlanságához füződő társadalmi érdek ${ }^{26}$, a másik álláspont szerint az orvostudományi kutatás törvényes rendje ${ }^{27}$. Azzal a felfogással nem lehet egyetérteni, amely az elkövetési tárgyakat (emberi génállomány, a magzat vagy az emberi embrió génállománya) tekinti jogi tárgynak. ${ }^{28}$

A születendö gyermek nemének megválasztása büntettének (Btk. 170. $\S^{29}$ ) jogi tárgya az egyik álláspont szerint a természeti törvények érvényesüléséhez, és ebből fakadóan a nemek közötti számbeli egyensúly fennmaradásához füződő társadalmi érdek ${ }^{30}$, a másik álláspont szerint az orvostudományi kutatás törvényes rendje ${ }^{31}$.

Az egészségügyi önrendelkezési jog megsértése büntettének és vétségének [Btk. 218. § (1), illetve (3) bek. ${ }^{32}$ ] jogi tárgya az egészségügyi beavatkozások területén érvényesülö önrendelkezési jog védelméhez füződő társadalmi érdek $^{33}$, pontosabban fogalmazva bármely, az egészségügyi ellátással vagy kutatással kapcsolatba kerülő, nem feltétlenül beteg személy egészségügyi önrendelkezési joga ${ }^{34}$.

Mindhárom büncselekmény közös abban, hogy tényállásában nincs paszszív alany megjelölve (a törvényi tényállásban megjelölt személy, akire az elkövetési magatartás irányul vagy behatást gyakorol), az elkövetési magatartás valamilyen beavatkozás végzése, a jogi tárgy pedig, ami nem individuális, hosszabb időn át, a büncselekmény befejezettségét követően mindaddig sérthető, amíg az elkövetö - akár több - beavatkozást végez.

\section{Kutatás végzése}

Az idetartozó egyik büncselekmény az emberen végezhetö kutatás szabályainak megszegése (Btk. 171. $\S^{35}$ ). A büncselekmény jogi tárgya az alapvető emberi jogok védelméhez, illetve az orvostudományi kutatás biztonságához füződő társadalmi érdek ${ }^{36}$, illetve az orvostudományi kutatás törvényes rendje ${ }^{37}$. A büncselekmény elkövetési tárgya az ember, ez viszont nem konkretizált passzív alany. Az elkövetési magatartás a kutatás végzése, ami természetéből adódóan egy hosszabb folyamatot jelent. Mindebből az következik, hogy mivel a jogi tárgy hosszabb időn át sérthetö, a büncselekménynek nincs passzív 
alanya, az elkövetési magatartás pedig egy folyamatos tevékenységet jelöl meg, nem kizárt, hogy a befejezettségtől a bevégzettség elkülönüljön.

A másik idetartozó büncselekmény az embrióval vagy ivarsejttel végezhetö kutatás szabályainak megszegése [Btk. 172. § (1) bek. ${ }^{38}$, illetve 173. § (1) bek. $\left.{ }^{39}\right]$. A büncselekmény mindkét tényállásának jogi tárgya az orvostudományi kutatás törvényességéhez füződő társadalmi érdek. ${ }^{40} \mathrm{Az}$ (1) bekezdés szerinti változat elkövetési tárgya az emberi ivarsejt, illetve az emberi embrió, a (2) bekezdés szerinti változaté az emberi embrió. Az elkövetési magatartás a kutatás végzése, ami természetéből adódóan egy hosszabb folyamatot jelent.

Összegezve, azoknál a büncselekményeknél, amelyek jogi tárgya hoszszabb időn át sérthető, a tényállás nem tartalmaz passzív alanyt, az elkövetési magatartás pedig jellegéből adódóan (kutatás végzése) folyamatos tevékenységet jelöl meg, nem kizárt, hogy a befejezettségtől elkülönüljön a bevégzetti szak.

\section{Tevékenység végzése}

A kábitószer-prekurzorral visszaélés büntettének (Btk. 183. § $\left.\S^{41}\right)$ jogi tárgya a polgárok egészségének, az emberi egészség védelméhez füződő társadalmi $e^{\prime r d e{ }^{42}}$. Elkövetési tárgya a kábítószer-prekurzor, passzív alany nem szerepel a tényállásban. Az elkövetési magatartások közül a közvetítö tevékenység végzése [Btk. 183. § (1) bek. a) pont] minden olyan, jegyzékben szereplö anyag vásárlásának és eladásának vagy szállításának megszervezésére irányuló tevékenység, amelyet bármely természetes vagy jogi személy két fél közötti megállapodás elérése céljával, vagy legalább az említett felek egyikének nevében eljárva végez anélkül, hogy az említett anyagokat a birtokába venné, vagy az ilyen ügylet lebonyolítását irányítaná; ez a fogalommeghatározás úgyszintén kiterjed minden olyan, a Közösségben letelepedett bármely természetes vagy jogi személy által végzett tevékenységre, amely jegyzékben szereplő anyagok vásárlását és eladását vagy szállítását foglalja magában anélkül, hogy az említett anyagokat a Közösség vámterületére bejuttatnák [a Tanács kábítószer-prekurzoroknak a Közösség és harmadik országok közötti kereskedelme nyomon követésére vonatkozó szabályok megállapításáról szóló 111/2005/EK rendelete, 2. cikk e) pont]. ${ }^{43}$

Az orvvadászat büntettének (Btk. 245. §44) és az orvhalászat vétségének (Btk. 246. §5) jogi tárgya a természet védelme, a vadállomány védelméhez, észszerü hasznosításához, illetve a halászati jog szabályszerü gyakorlásához füződő társadalmi érdek ${ }^{46}$. Passzív alanyt egyik tényállás [Btk. 245. § a), illet- 
ve c) pont, 246. §] sem tartalmaz. Az orvvadászat büntettének a téma szempontjából jelentős elkövetési magatartása a vad elejtésére vagy elfogására irányuló tevékenység végzése [Btk. 245. § a) és c) pont], ami nem azonos a vad elejtésével vagy elfogásával, tekintve, hogy ezeket az elkövetési magatartásokat a törvény külön nevesíti [Btk. 245. § b) pont]. Az orvhalászat elkövetési magatartása a halfogásra irányuló tevékenység végzése. A halászat fogalmát jelenleg a halgazdálkodásról és a hal védelméről szóló 2013. évi CII. törvény 2 . §-ának 9. pontja határozza meg, e szerint: a halnak vagy más hasznos víziállatnak megengedett módon és eszközzel halgazdálkodási vízterületen történő rekreációs vagy kereskedelmi célú, illetve ökológiai célú, szelektív fogása, továbbá gyüjtése, ide nem értve a horgászatot. Az orvvadászat tényállásának logikájából következően, a hal fogása nem tartozik a halfogásra irányuló tevékenység végzése alá, az orvhalászat tényállásból következöen - összhangban a halászat definíciójával - a horgászat sem, így valójában a hal gyüjtése marad egyedül értékelhető a fogalommeghatározásból, ami viszont egy akár hosszabb időn át kifejthető tevékenységet jelent.

A hulladékgazdálkodás rendjének megsértése büntettének (Btk. 248. $\S^{47}$ ) jogi tárgya az egészséges emberi és természeti környezet fenntartásához, a környezetre veszélyes hulladékokkal kapcsolatos elöírások megtartásához füződő társadalmi érdek ${ }^{48}$. A büncselekmény passzív alanyt nem tartalmaz. A téma szempontjából jelentős elkövetési magatartás a hulladékgazdálkodási tevékenység, illetve a hulladékkal más jogellenes tevékenység végzése [Btk. 248. § (1) bek. a) pont]. Az elkövetési magatartás értelmezéséhez segítséget maga a törvény nyújt, ugyanis meghatározza a hulladékgazdálkodási tevékenység fogalmát: a hulladéknak a hulladékról szóló törvényben meghatározott gyüjtése, begyüjtése, szállítása - ideértve az országba történő behozatalt, onnan történő kivitelt, valamint az azon történő átszállítást -, előkezelése, tárolása, hasznosítása, ártalmatlanítása.

A zugírászat vétségének (Btk. 286. $\S^{49}$ ) jogi tárgya a jogkereső polgárok érdekeinek oltalmazásához ${ }^{50}$, az igazságszolgáltatás és a jogi vonatkozású ügyek szakszerü és szabályszerü intézésének rendjéhez füződő társadalmi érdek ${ }^{51}$. A tényállás passzív alanyt nem tartalmaz, és valójában elkövetési tárgyat sem. A büncselekmény elkövetési magatartása az ügyvédi, jogtanácsosi vagy közjegyzői tevékenység jogosulatlan és üzletszerü végzése [Btk. 286. § (1) bek.]. Megjegyezendő, hogy az alapeseti üzletszerüség törvényi egységet teremt. ${ }^{52}$ Ugyanakkor az elkövetési magatartásként megjelölt ügyvédi stb. tevékenység végzése eleve olyan jellegủ magatartást jelent, amely akár hosszabb időn át 
folytatható, így például ilyen az ügyfél képviselete, jogi, pénzügyi tanácsadás, szerződések, beadványok, okiratok készítése stb.

A gazdasági csalás [Btk. 374. § (1) bek. ${ }^{53}$ jogi tárgya a tulajdonjogból és a kötelmi jogviszonyokból származó vagyoni jog, illetve a gazdasági tevékenység valódiságához füződő társadalmi érdek. ${ }^{54}$ Nem kívánva belemenni részletesen a tényállás elemzésébe, annyit érdemes megemlíteni, hogy jókora problémák adódnak a büncselekmény értelmezése kapcsán. Véleményem szerint a büncselekmény törvényi tényállásában passzív alany nem szerepel, eredmény azonban igen. Ebböl következően a büncselekménynek csak sértettje lehet, mégpedig az, akinél a kár bekövetkezik, passzív alanya azonban nincs. Ezzel szemben Sinku Pál szerint a büncselekmény passzív alanya a vagyoni hátrányt szenvedett gazdasági társaság, magánszemély. ${ }^{55}$ Fel kell hívni a figyelmet arra, hogy az elkövetési tárgy (és így a passzív alany is) a törvényi tényállásban megjelölt dolog vagy személy lehet csupán. Szomora Zsolt - Sinkuval szemben - azt írja, hogy a büncselekménynek sem elkövetési tárgya, sem passzív alanya nincs, illetve a törvényi tényállás szövegezéséböl még csak a sértett személyére sem lehet következtetni. ${ }^{56} \mathrm{Az}$ állítás első részével kétségtelenül egyet lehet érteni, a sértett személyére való következtetés megkövetelését a szerző nem fejti ki bővebben, pontosabban később arra utal, hogy passzív alany hiányában nem világos az, hogy a színlelés kit téveszt meg és kinek okoz vagyoni hátrányt. A csalásnál [Btk. 373. § (1) bek.], ahol a tényállás passzív alanyt tartalmaz, és eredményként a kár okozását, sem feltétlenül biztos, hogy a passzív alany lesz egyben a sértett is.

Az elkövetési magatartás értelmezése sem problémamentes. Sinku szerint színlelt gazdasági tevékenységnek azt tekinthetö, ,ha a felek, az abban közremüködök akarata nem áll összhangban az általuk ténylegesen kifejtésre juttatott tevékenységgel. Az adott gazdasági tevékenység tényleges teljesitésére nem kerül sor, az adott tevékenység a társaság szempontjából felesleges, a gazdasági tevékenység »ellenértéke irreális. Lényeges, hogy a gazdasági tevékenységben részt vevö személyek a tényeket illetöen nincsenek tévedésben, a csalási tevékenység látszatát közösen hozzák létre. ${ }^{{ }_{57}}$ Ezzel szemben - és egyben egyet is lehet érteni vele - Szomora arra hívja fel a figyelmet, hogy mindez jól írja körül a színlelés lényegét, azonban az nem derül ki belőle, hogy tulajdonképpen mit kell gazdasági tevékenységen érteni. ${ }^{58}$ Megoldási lehetőségként Szomora felveti a személyi jövedelemadóról szóló 1995. évi CXVII. törvény értelmező rendelkezését, amely szerint gazdasági tevékenység: valamely tevékenység üzletszerü, illetőleg tartós vagy rendszeres jelleggel történő folytatása, amennyiben az ellenérték elérésére irányul, vagy azt 
eredményezi, és annak végzése független formában történik (3. § 46. pont). Viszont arra is utal, hogy a Btk.-beli tényállás nem keretdiszpozíció, ezért e fogalom automatikus alkalmazhatósága legalábbis kérdéses. ${ }^{59}$ Szomora szerint valójában a gazdasági tevékenység - legalábbis egyelöre - határozatlan fogalom a büntetőjogban. ${ }^{60}$ Ami Szomora elemzéséből a téma szempontjából kiemelendő, hogy felhívja a figyelmet arra, hogy a végez kifejezés elvileg huzamosabb, ismétlődő tevékenységet feltételez. ${ }^{61}$

A pénzmosás büntettét és vétségét, illetve a jogosulatlan pénzügyi tevékenység büntettét ebben a körben együtt érdemes tárgyalni, mivel az elkövetési magatartások lényegében ugyanazok.

A pénzmosás jogi tárgya a szervezett bünözés elleni hatékony küzdelemhez füződő társadalmi érdek, illetve a pénzügyi intézmények és a gazdaság egyéb szereplőinek törvényes müködéséhez füződő közérdek ${ }^{62}$. A téma szempontjából két változat érdemel említést. Az egyik a más által elkövetett büntetendő cselekményből származó dologgal összefüggésben bármilyen pénzügyi tevékenység végzése [Btk. 399. § (1) bek. a) pont] ${ }^{63}$, a másik a más által elkövetett büncselekményből származó dologgal összefüggésben bármilyen pénzügyi tevékenység végzése [Btk. 400. § (1) bek. b) pont ${ }^{64}$. Egyik változat sem tartalmaz passzív alanyt, elkövetési tárgy a meghatározott dolog ${ }^{65}$. Az elkövetési magatartás mindkét esetben a (bármilyen) pénzügyi tevékenység végzése. A pénzügyi tevékenység fogalmát értelmező rendelkezés határozza meg, e szerint pénzügyi tevékenységen, illetve pénzügyi szolgáltatás igénybevételén a pénzügyi szolgáltatási vagy kiegészítő pénzügyi szolgáltatási, befektetési szolgáltatási vagy befektetési szolgáltatási tevékenységet kiegészítő szolgáltatási, árutőzsdei szolgáltatási, befektetésialap-kezelési, kockázatitőkealap-kezelési, tőzsdei, elszámolóházi, központi értéktári vagy központi szerződő fél, vagy biztosítási, viszontbiztosítási vagy független biztosításközvetítői, illetve önkéntes kölcsönös biztosító pénztári, magánnyugdíjpénztári vagy foglalkoztatói nyugdíjszolgáltatási tevékenységet, illetve annak igénybevételét kell érteni [Btk. 402. § (2) bek.].

A jogosulatlan pénzügyi tevékenység bủntettének (Btk. 408. $\left.\S^{66}\right)$ jogi tárgya a tőkepiac szabályos müködéséhez és a pénzügyi szolgáltatások törvényes müködéséhez füződő gazdasági érdek ${ }^{67} \mathrm{~A}$ tényállás sem elkövetési tárgyat, sem passzív alanyt nem jelöl meg. Az elkövetési magatartások megegyeznek a pénzmosáshoz füzött értelmező rendelkezés szerinti tevékenységek végzésével.

Ezeknek a részmagatartásoknak a meghatározása meghaladná a tanulmány kereteit ${ }^{68}$, néhány dolgot azért érdemes rögzíteni. Egyrészt fel kell hív- 
ni a figyelmet arra, hogy a pénzügyi és a kiegészítő pénzügyi szolgáltatás fogalma alá bizonyos tevékenységek üzletszerü végzése tartozik ${ }^{69}$; a befektetési szolgáltatási tevékenység és árutőzsdei tevékenység pedig csak rendszeres gazdasági tevékenység keretében végezhető ${ }^{70}$. Másrészt érdemes felidézni Molnár Gábor Miklós azon megállapítását, miszerint e tevékenységek ,közös ismérve azok rendszeres tevékenység keretében történö (ismétlődö) folytatása. Ezért a rendbeliség megitélése körében közömbös az egyes pénzügyi tevékenységek típusa, száma, illetve a ténylegesen lebonyolitott ügyletek száma egyaránt, mert mindezek természetes egységbe olvadnak. "7l

Összegezve, az elöbbiekben ismertetett büncselekmények esetén, ahol a jogi tárgy hosszabb időn át sérthető, a tényállás nem tartalmaz passzív alanyt, az elkövetési magatartás pedig jellegéből adódóan (tevékenység végzése) huzamosabb, ismétlődő vagy folyamatos tevékenységet jelöl meg, nem kizárt, hogy a befejezettségtől elkülönüljön a bevégzetti szak.

Szexuális cselekmény végzése

A szexuális cselekmény a hatályos Btk. újítása, amely valójában a korábbi Btk. szerinti közösülés és fajtalanság fogalmát egyesíti, illetve némiképp kibővíti. A hatályos törvény szerint szexuális cselekmény a közösülés, és minden olyan súlyosan szeméremsértő cselekmény, amely a nemi vágy felkeltésére, fenntartására vagy kielégítésére alkalmas, vagy arra irányul [Btk. 459. § (1) bek. 27. pont].

A szexuális cselekmény végzése a hatályos Btk.-ban három büncselekmény tényállásában szerepel önálló elkövetési magatartásként, ezek:

a) a szexuális erőszak: aki tizenkettedik életévét be nem töltött személlyel szexuális cselekményt végez [Btk. 197. § (2) bek.];

b) a szexuális visszaélés: az a tizennyolcadik életévét betöltött személy, aki tizennegyedik életévét be nem töltött személlyel szexuális cselekményt végez, illetve az a tizennyolcadik életévét betöltött személy, aki tizennegyedik életévét betöltött, de tizennyolcadik életévét be nem töltött személlyel a vele kapcsolatban fennálló hatalmi vagy befolyási viszonyával visszaélve szexuális cselekményt végez [Btk. 198. § (1), illetve (4) bek.]; és

c) a vérfertőzés: aki egyenes ági rokonával szexuális cselekményt végez [Btk. 199. § (1) bek.]

Más bủncselekmények esetén a szexuális cselekményhez valamilyen másik elkövetési magatartás vagy elkövetési mód is társul: 
a) szexuális kényszerítés esetén: szexuális cselekményre (vagy annak eltürésére) kényszerítés [Btk. 196. § (1) bek.];

b) szexuális erőszak esetén: a szexuális cselekményt magában foglaló szexuális kényszerítést erőszakkal vagy minősített fenyegetéssel követik el [Btk. 197. § (1) bek. a) pont];

c) szexuális erőszak esetén: más védekezésre vagy akaratnyilvánításra képtelen állapotát szexuális cselekményre használja fel [Btk. 197. § (1) bek. b) pont].

A szexuális kényszerítés és a szexuális erőszak jogi tárgya az egyén szexuális önrendelkezése, a szexuális visszaélésé a gyermek zavartalan szexuális fejlődése, a vérfertőzésé pedig a nemi erkölcs. ${ }^{72}$ A vérfertőzés kivételével (ami találkozó-büncselekmény) mindegyik tényállás passzív alanyt tartalmaz, aminek a büncselekmény rendbeliségére meghatározó jelentősége van.

A szexuális cselekmény befejezetten megvalósul adott esetben a sértett vagy a tettes nemi szervének, vagy akár a sértett saját nemi szervének érintésével. ${ }^{73} \mathrm{~A}$ szexuális cselekmény azonban az érintést követően időben tovább tarthat, és ebben az esetben mindeddig fennáll a jogi tárgy sérelme.

Mindennek természetesen megvannak a maga konzekvenciái. Az első az elkövetői minőségre vonatkozik. Általában igaz az, hogy az olyan büncselekmények esetén, amikor a befejezettségtől elkülöníthető a bevégzettség stádiuma, a jogi tárgy sérelmének fennállása alatt társtettesi vagy bűnsegédi közremüködés kifejthető. Ez természetesen csak addig igaz, amíg a tényállás szerkezete ezt nem zárja ki. A szexuális erőszak azon eseteiben, amelyet eröszakkal, minősített fenyegetéssel, vagy a sértett védekezésre vagy akaratnyilvánításra képtelen állapotát kihasználva követnek el [Btk. 197. § (1) bek.], ha a szexuális cselekményt azonos alkalommal, egymás cselekményéről tudva, többen követik el [Btk. 197. § (3) bek. c) pont], a több elkövető nem társtettes lesz, hanem önálló tettes. Úgyszintén, a két egyenes ági rokon vérfertőzést megvalósító szexuális cselekményébe [Btk. 199. § (1) bek.] harmadikként bekapcsolódó egyenes ági rokon szintén önálló tettese lesz a büncselekménynek. A bünsegédi közremüködésre - mint tényálláson kívüli magatartásokra - ez természetesen nem vonatkozik.

A jogos védelem lehetősége fennáll a befejezettség és a bevégzettség között, mint ahogy minősítő körülmény is megvalósítható. A büncselekmény hacsak a sértettek száma nem változtat rajta - egyrendbelinek minősül a két stádium szétválásának ellenére, és az elévülés is a bevégzettséghez kötődik. 
Engedélyhez kötött titkos információgyüjtés,

illetve titkos adatszerzés engedély nélküli végzése

A jogosulatlan titkos információgyüjtés vagy adatszerzés bűntettének (Btk. 307. $\S^{74}$ ) jogi tárgya az állami szervek törvényes müködésébe vetett biza$\operatorname{lom}^{75}$, illetve a magántitokhoz, a titkos információgyüjtés és adatszerzés szabályosságához füződő társadalmi érdek ${ }^{76}$. A büncselekményi tényállás elkövetési tárgyat, passzív alanyt nem tartalmaz. Téves az a felfogás, amely szerint a büncselekmény passzív alanya az lenne, akivel szemben jogosulatlanul történik a titkos információgyüjtés/adatszerzés. ${ }^{77} \mathrm{Ez}$ a személy a büncselekmény sértettje (az ö jogát vagy jogos érdekét sérti a bủncselekmény), de nem passzív alanya, mivel a tényállásban nincs nevesítve.

A téma szempontjából releváns elkövetési magatartás az engedélyhez kötött titkos információgyüjtés, illetve titkos adatszerzés engedély nélküli végzése [Btk. 307. § (1) bek. a) pont]. Az elkövetési magatartások tartalmát a titkos információgyưjtést/adatszerzést szabályozó törvények adják meg, ezekre a téma szempontjából nem szükséges részletesen kitérni. Annyit kell csupán rögzíteni, hogy olyan tevékenységek tartoznak ide, mint a lakás titokban való átkutatása, a lakásban történtek technikai eszközzel való megfigyelése, rögzítése, elektronikus hírközlési szolgáltatás vagy számítástechnikai eszköz, rendszer útján továbbított adat tartalmának megismerése, rögzítése. Ezek mind olyan magatartások, amelyek megkezdésével a büncselekmény befejeződik, viszont a jogsérelem fennáll a tevékenység végzése alatt.

Megbízhatósági vizsgálat ügyészi jóváhagyás nélküli végzése

A jogosulatlan megbízhatósági vizsgálat végzése büntettének (Btk. 308. $\left.\S^{78}\right)$ jogi tárgya a hivatali apparátusba és a megbízhatósági vizsgálat törvényességébe vetett bizalom. ${ }^{79} \mathrm{~A}$ büncselekményi tényállás - az előző tényállásnál tett megjegyzésekkel - nem tartalmaz elkövetési tárgyat vagy passzív alanyt. Elkövetési magatartása a megbízhatósági vizsgálat ügyészi jóváhagyás nélküli végzése [Btk. 308. § (1) bek. a) pont]. A rendőrségről szóló 1994. évi XXXIV. törvényből az következik, hogy a megbízhatósági vizsgálat megindítása és befejezése időben elválik egymástól [7/A § (3) bek.], a vizsgálat végzése tehát e két időpont között történik, ami a jogi tárgy folyamatos sérelmét teszi lehetövé. 


\section{Az állapot-büncselekmények atipikus esete}

Kétségtelen, hogy az előzőekben ismertetett tényállások is atipikusak az állapot-büncselekmények értelmezését tekintve. Ezeknél viszont az elkövetési magatartás megfogalmazása hordozza magában annak lehetőségét, hogy a befejezettség és a bevégzettség elváljon. A rágalmazás/becsületsértés büncselekménye azonban még atipikusabb. A témához való kapcsolódást az adja, hogy ezeket nemcsak szóbeli közléssel lehet elkövetni, hanem akár írásban, rajzban, képes ábrázolással, vagy nyomtatvány útján is. ${ }^{80}$ Ráadásul a rágalmazás körében minősítő körülményként [Btk. 226. § (2) bek. b) pont], a becsületsértés tényállásában pedig alaptényállási elemként [Btk. 227. § (1) bek. b) pont] szereplő nagy nyilvánosságon az értelmező rendelkezés szerint a büncselekménynek a sajtótermék, médiaszolgáltatás, sokszorosítás vagy elektronikus hírközlö hálózaton való közzététel útján történő elkövetését is érteni kell [Btk. 459. § (1) bek. 22. pont]. Ezekben az esetekben, ha a rágalmazást vagy becsületsértést megvalósító cselekményt nem verbálisan realizálja az elkövető, hanem mondjuk rajzzal, nyomtatvánnyal, vagy az interneten teszi közzé, egy olyan jogellenes állapotot hoz létre, ami addig tart, amíg a rágalmazásra vagy becsületsértésre alkalmas közlést el nem távolítják. Ez a változata a büncselekménynek tehát valójában úgy viselkedik, mint az állapot-büncselekmény. Kérdésként vetödik fel, hogy annak minden konzekvenciája tartható-e. Például, ha valaki becsület csorbítására alkalmas tényre utaló kifejezést írásban kifüggeszt valahova, és ehhez egy addig kívülálló még hozzáír vagy hozzárajzol egy szintén a becsület csorbítására alkalmas kifejezést vagy ábrát, a büncselekménynek társtettese lesz? A társtettesség fogalma megköveteli, hogy az elkövetők egymás tevékenységéről tudva, közösen valósítsák meg a szándékos büncselekmény törvényi tényállását. A példaként felhozott esetben az első vagy eredeti rágalmazást megvalósító elkövetőnek nyilvánvalóan nincs tudomása egy későbbi, számára akár ismeretlen elkövető tevékenységéről. A jogos védelem lehetősége szintén kérdéses. Elvileg elképzelhető, hogy mondjuk a falfirkával elkövetett rágalmazást vagy becsületsértést a falfirka lefújásával hárítja el valaki, ami a rongálás vétségét valósíthatja meg védelmi cselekményként. Sőt, mivel a jogos védelem szabálya lehetőséget nyújt a más személye ellen intézett jogtalan támadás elhárítására, vajon bárki lefújhatja a nyilvánvalóan rágalmazást vagy becsületsértést megvalósító falfirkát?

A mai technikai és társadalmi fejlettséget alapul véve nem hagyható el annak lehetősége, hogy a rágalmazást/becsületsértést megvalósító cselekmény 
interneten történik, például egy közösségi oldalon közzétett formában. Az ehhez írt, csatlakozó komment szerzője sem lesz társtettese a büncselekménynek, az előzőekben írt probléma miatt.

\section{Összegzés}

Az előzőek figyelembevételével, a jogellenes állapot fenntartásával megvalósuló (állapot-) bủncselekmények újabb kérdéseket vetnek fel, amelyekkel talán érdemes foglalkozni. A tipikusnak tekintett eseteken túl (löfegyverrel/lőszerrel visszaélés, személyi szabadság megsértése) vannak olyan büncselekményi tényállások, amelyek esetén alappal vetődhet fel a jogi tárgy elleni támadás elhúzódása, a befejezettség és a bevégzettség stádiumának szétválása.

Azon büncselekmények esetén, amelyek jogi tárgya hosszabb időn át sérthetö, a tényállás nem tartalmaz passzív alanyt, az elkövetési magatartás megfogalmazására pedig valamilyen tevékenység vagy cselekmény folytatásában, végzésében került sor, nem kizárt, hogy a befejezettségtől elkülönüljön a bevégzetti szak. Ugyanígy lehetőség van erre olyan büncselekmények esetén is, mint a rágalmazás/becsületsértés vétsége. A büntetőjogi felelősség kérdésében ezekben az esetekben rendkívül körültekintően kell eljárni.

\section{LÁBJEGYZETEK}

1 254. § A ki valamely gyermeket más családba csempész, kicserél, elsikkaszt, eltitkol, rendszerint járt helyre kitesz, vagy bármely más módon családi állásától megfoszt, vagy ezen állását megváltoztatja: a családi állás elleni büntettet követi el, és egy évig terjedhető börtönnel büntetendő.

2 251. § A ki érvényes házassági kötelékben lévén, ismét házasságra lép, ugyszintén azon nem házas is, ki tudva, oly egyénnel házasságot köt: a kettős házasság büntettét követi el, és három évig terjedhető börtönnel büntetendő.

3 303. § Öt évig terjedhető börtönnel büntetendő a testi sértés, ha annak következtében a sérült, testének valamely nevezetesebb tagját, vagy érzékét, beszélő, halló, látó vagy nemző tehetségét elvesztette; ha e tagok, érzékek vagy tehetségek valamelyike használhatatlanná lett; ha a sérült nyomorékká vált; ha elméje megzavarodott: ha előreláthatólag hosszu ideig tartó betegségbe esett, vagy rendes foglalkozásának folytatására végkép, - vagy előreláthatólag hosszu időre képtelenné vált, vagy feltünően eltorzittatott.

4 Angyal Pál: A magyar büntetőjog tankönyve. Athenaeum Kiadó, Budapest, 1920, 482-483. o.

5 Heller Erik: A magyar büntetőjog általános tanai. Grill, Budapest, 1945, 89. o.

6 A büntetőtörvénykönyv általános része. Jogi és Államigazgatási Könyv- és Folyóiratkiadó, Budapest, 1951, 83-84. o.

7 Tokaji Géza: A büncselekménytan alapjai a magyar büntetőjogban. KJK, Budapest, 1984, 298. o.

8 Wiener A. Imre: Büntetendőség - büntethetőség (felelősségtan). In: Wiener A. Imre (szerk.): Büntetendőség - Büntethetőség. Büntetőjogi tanulmányok. KJK-Kerszöv, Budapest, 2000, 184. o. 
9 Földvári József: Magyar büntetőjog. Általános rész. Osiris Kiadó, Budapest, 2006, 89. o.

10 Uo.182. o.

11 Békés Imre (szerk.): Büntetőjog. Általános rész. HVG-ORAC, Budapest, 2003, 106. o.

12 Uo.

13 Uo. 181. o.

14 Uo. 182. o.

15 Uo. 175. o.

16 Nagy Ferenc: A magyar büntetőjog általános része. HVG-ORAC, Budapest, 2010, 205. o.

17 Kádár Krisztina - Moldoványi György (szerk.): Büntető törvénykönyv. KJK, Budapest, 1979, 73. o.

18 Belovics Ervin - Molnár Gábor - Sinku Pál: Büntetőjog II. HVG-ORAC, Budapest, 2012, 494. o.

19 Karsai Krisztina (szerk.): Kommentár a Büntető Törvénykönyvhöz. Complex Kiadó, Budapest, 2013, 670. o.

20 Uo. 360. o.; Kónya István (szerk.): Magyar büntetőjog. Kommentár a gyakorlat számára I. HVGORAC, Budapest, 2015, 624-625. o.

$21 \mathrm{BH}, 1997 / 512$.

22 Ambrus István: Egység - halmazat. Régi dogmatikai kérdés, új megközelítésben. Szegedi Tudományegyetem Állam- és Jogtudományi Kar Büntetőjogi és Büntető Eljárásjogi Tanszék, Szeged, 2014, 64. o.

23 Mészáros Ádám: A büncselekmény elkövetői. Elméleti és gyakorlati alapkérdések. Ad Librum, Budapest, 2008, 95-96. o.

24 Nagy Ferenc: i. m. 206. o.

25 168. § (1) Aki az emberi vagy magzati génállományon, illetve emberi embrió génállományán annak megváltoztatására irányuló beavatkozást végez, büntett miatt egy évtől öt évig terjedő szabadságvesztéssel büntetendő

26 Belovics Ervin - Molnár Gábor - Sinku Pál: i. m. 110. o.

27 Karsai Krisztina (szerk.): i. m. 338. o.

28 Kónya István (szerk.): i. m. 603. o.

29 170. § Aki a születendő gyermek nemének megválasztására irányuló beavatkozást végez, bűntett miatt egy évtől öt évig terjedő szabadságvesztéssel büntetendő.

30 Belovics Ervin - Molnár Gábor - Sinku Pál: i. m. 113. o.

31 Karsai Krisztina (szerk.): i. m. 340. o.

32 218. § (1) Aki beleegyezéshez vagy hozzájáruláshoz kötött

a) az emberi génállomány megváltoztatásával, az embrió génállományának megváltoztatásával, emberi reprodukcióval vagy a születendő gyermek nemének megválasztásával kapcsolatos egészségügyi beavatkozást,

b) emberen, embrióval vagy ivarsejttel végezhető orvostudományi kutatást,

c) az átültetés céljából végzett szerv- vagy szövetkivételt, illetve szerv- vagy szövetátültetést

a jogosult beleegyezése vagy hozzájárulása nélkül végez, vagy a beleegyezés és a hozzájárulás jogának gyakorlásához szükséges, törvényben elöirt megfelelö tájékoztatást elmulasztja, bűntett miatt három évig terjedő szabadságvesztéssel büntetendő.

(3) Aki a beleegyezéshez vagy hozzájáruláshoz kötött, az (1) bekezdés szerinti egészségügyi beavatkozást, orvostudományi kutatást, szerv- vagy szövetkivételt, illetve szerv- vagy szövetátültetést gondatlanságból a jogosult beleegyezése vagy hozzájárulása nélkül végez, vétség miatt egy évig terjedő szabadságvesztéssel büntetendő.

33 Belovics Ervin - Molnár Gábor - Sinku Pál: i. m. 232. o.

34 Karsai Krisztina (szerk.): i. m. 456. o.

35 171. § Aki emberen orvostudományi kutatást engedély nélkül vagy az engedélytől eltérően végez, büntett miatt egy évtől öt évig terjedő szabadságvesztéssel büntetendő.

36 Belovics Ervin - Molnár Gábor - Sinku Pál: i. m. 114. o.

37 Karsai Krisztina (szerk.): i. m. 342. o. 
38 172. § (1) Aki emberi ivarsejten, illetve emberi embrión engedély nélkül vagy az engedélytől eltérően orvostudományi kutatást végez, vagy emberi embriót kutatási célból hoz létre, büntett miatt egy évtől öt évig terjedő szabadságvesztéssel büntetendő.

39 173. § (1) Aki emberi embrión az embrió génállományának megváltoztatására irányuló kutatást végez, büntett miatt egy évtől öt évig terjedő szabadságvesztéssel büntetendő.

40 Belovics Ervin - Molnár Gábor - Sinku Pál: i. m. 116. o.; Karsai Krisztina (szerk.): i. m. 345. o.

41 183. § (1) Aki az Európai Unió jogi aktusában meghatározott kábítószer-prekurzort

a) engedély nélkül vagy az engedély kereteit túllépve tart, forgalomba hoz, szállít, vagy azzal közvetítő tevékenységet végez,

b) úgy szerez meg, hogy evégből valótlan tartalmú nyilatkozatot tesz, büntett miatt három évig terjedő szabadságvesztéssel büntetendő.

42 Belovics Ervin - Molnár Gábor - Sinku Pál: i. m. 137. o.; Karsai Krisztina (szerk.): i. m. 370. o.

$43 \mathrm{http}: /$ eur-lex.europa.eu/legal-content/HU/ALL/?uri=CELEX:32005R0111

$44245 . \S$ Aki

a) vadászterületen vadászatra való jogosultság nélkül, illetve idegen vadászterületen vadászként engedély nélkül vad elejtésére vagy elfogására irányuló tevékenységet végez,

b) külön jogszabályban meghatározott, a vadfaj valamennyi egyedére kiterjedő vadászati tilalmi idő hatálya alá eső vadfaj egyedét ejti vagy fogja el,

c) külön jogszabályban meghatározott tiltott vadászati eszközzel, tiltott vadászati módon vagy kíméleti területen vad, illetve fokozottan védett vagy védett gerinces állat elejtésére vagy elfogására irányuló tevékenységet végez, bűntett miatt három évig terjedő szabadságvesztéssel büntetendő.

45 246. § Aki

a) jogosulatlanul halászhálóval vagy más halászati eszközzel - a horgászatot kivéve - halfogásra irányuló tevékenységet végez,

b) külön jogszabályban meghatározott tiltott eszközzel, tiltott módon vagy kíméleti területen halfogásra irányuló tevékenységet végez, vétség miatt két évig terjedő szabadságvesztéssel büntetendő.

46 Belovics Ervin - Molnár Gábor - Sinku Pál: i. m. 318., 320. o.; Karsai Krisztina (szerk.): i. m. 516. , 518. o.

$47248 . \S(1)$ Aki

a) arra a célra hatóság által nem engedélyezett helyen hulladékot elhelyez,

b) engedély nélkül vagy az engedély kereteit túllépve hulladékgazdálkodási tevékenységet, illetve hulladékkal más jogellenes tevékenységet végez,

büntett miatt három évig terjedő szabadságvesztéssel büntetendő.

48 Belovics Ervin - Molnár Gábor - Sinku Pál: i. m. 323. o.; Karsai Krisztina (szerk.): i. m. 521. o.

49 286. § (1) Aki jogosulatlanul és üzletszerủen ügyvédi, jogtanácsosi vagy közjegyzői tevékenységet végez, vétség miatt két évig terjedő szabadságvesztéssel büntetendő.

50 Belovics Ervin - Molnár Gábor - Sinku Pál: i. m. 416. o.

51 Karsai Krisztina (szerk.): i. m. 587. o.

52 Nagy Ferenc: i. m. 239. o.

53 374. § (1) Aki jogtalan haszonszerzés végett színlelt gazdasági tevékenységet végez, és ezzel vagyoni hátrányt okoz, gazdasági csalást követ el.

54 Belovics Ervin - Molnár Gábor - Sinku Pál: i. m. 621. o.

55 Uo.

56 Karsai Krisztina (szerk.): i. m. 784. o.

57 Belovics Ervin - Molnár Gábor - Sinku Pál: i. m. 621. o.

58 Karsai Krisztina (szerk.): i. m. 785. o.

59 Uo. 784-785. o.

60 Uo. 784. o.

61 Uo. 785. o. 
62 Belovics Ervin - Molnár Gábor - Sinku Pál: i. m. 706. o.

63 399. § (1) Aki más által elkövetett büntetendő cselekményből származó

a) dolgot átalakítja, átruházza, vagy a dologgal összefüggésben bármilyen pénzügyi tevékenységet végez, vagy pénzügyi szolgáltatást vesz igénybe abból a célból, hogy

aa) az ilyen dolog eredetét eltitkolja, elleplezze, vagy

ab) a más által elkövetett büntetendő cselekmény elkövetőjével szemben folytatott büntetőeljárást meghiúsítsa,

b) [...] büntett miatt egy évtől öt évig terjedő szabadságvesztéssel büntetendő.

64 400. § (1) Aki a más által elkövetett büncselekményből származó

a) $[\ldots]$

b) dologgal összefüggésben bármilyen pénzügyi tevékenységet végez, vagy pénzügyi szolgáltatást vesz igénybe, és gondatlanságból nem tud a dolog ezen eredetéről, vétség miatt két évig terjedő szabadságvesztéssel büntetendő.

65 Ennek értelmezéséhez lásd Btk. 402. § (1) bek.

66 408. § Aki törvényben elöírt engedély nélkül

a) pénzügyi szolgáltatási vagy kiegészítő pénzügyi szolgáltatási,

b) befektetési szolgáltatási, illetve befektetési szolgáltatási tevékenységet kiegészítő szolgáltatási, árutőzsdei szolgáltatási, befektetési alapkezelési, kockázati tőkealap-kezelési, tőzsdei, elszámolóházi, központi értéktári vagy központi szerződő fél,

c) biztosítási, viszontbiztosítási vagy független biztosításközvetítési,

d) önkéntes kölcsönös biztosító pénztári, magán-nyugdíjpénztári vagy foglalkoztatói nyugdíj-szolgáltatási

tevékenységet végez, bűntett miatt három évig terjedő szabadságvesztéssel büntetendő

67 Karsai Krisztina (szerk.): i. m. 865. o.

68 Lásd ezeket részletesen Gál István: Pénzmosás. In: Polt Péter (főszerk.): Új Btk. kommentár. 8. kötet. Nemzeti Közszolgálati és Tankönyv Kiadó, Budapest, 2013, 64-74. o.; Belovics Ervin - Molnár Gábor - Sinku Pál: i. m. 763-772. o.

69 A hitelintézetekről és a pénzügyi vállalkozásokról szóló 2013. évi CCXXXVII. törvény 3. § (1)-(2) bek.

70 A befektetési vállalkozásokról és az árutőzsdei szolgáltatókról, valamint az általuk végezhető tevékenységek szabályairól szóló 2007. évi CXXXVIII. törvény 5. § (1) bek.; 9. § (1) bek.

71 Belovics Ervin - Molnár Gábor - Sinku Pál: i. m. 773-774. o.

72 Karsai Krisztina (szerk.): i. m. 403., 407., 412., 415. o.

73 Polt Péter (főszerk.): i. m. 4. kötet, 11. o.; Karsai Krisztina (szerk.): i. m. 980. o.

74 307. § (1) Az a hivatalos személy, aki bíró vagy az igazságügyért felelős miniszter engedélyéhez kötött titkos információgyüjtést, illetve titkos adatszerzést

a) engedély nélkül végez, vagy az engedély kereteit túllépi,

b) jogosulatlanul elrendel vagy engedélyez, bűntett miatt három évig terjedő szabadságvesztéssel büntetendő.

75 Karsai Krisztina (szerk.): i. m. 638. o.

76 Belovics Ervin - Molnár Gábor - Sinku Pál: i. m. 456. o.

77 Karsai Krisztina (szerk.): i. m. 638. o.; Belovics Ervin - Molnár Gábor - Sinku Pál: i. m. 456. o.

78 308. § (1) Az a hivatalos személy, aki megbízhatósági vizsgálatot

a) ügyészi jóváhagyás nélkül végez, vagy a jóváhagyás kereteit túllépi,

b) jogosulatlanul jóváhagy, bűntett miatt három évig terjedő szabadságvesztéssel büntetendő.

79 Karsai Krisztina (szerk.): i. m. 640. o.; Belovics Ervin - Molnár Gábor - Sinku Pál: i. m. 457. o.

80 Kónya István (szerk.): i. m. 873.; 884/2-3. o. 